\title{
Let's agree to disagree. \\ (Variation in) the assignment of gender to nominal anglicisms in Dutch
}

\begin{abstract}
In this paper, we investigate gender assignment to recently borrowed English loanwords in

Dutch, introducing several innovations to the field of gender assignment to anglicisms. First, we use multiple mixed-effects logistic regression to determine which factors underlie gender assignment in Dutch. As this model indicates that there is variation in the amount of homogeneity in the speech community (i.e. agreement between respondents) concerning the gender assigned to an anglicism, we analyze the contexts in which homogeneity is the lowest. This analysis reveals that the amount of agreement does not solely depend on the degree of establishment of an anglicism. In contrast to what has been argued in previous studies, gender assignment to anglicisms in Dutch is not a categorical process.
\end{abstract}

\section{Keywords}

anglicism, gender assignment, gender variation, quantitative analysis, Dutch

\section{Acknowledgements}


We are grateful to Dirk Geeraerts and to two anonymous referees for useful comments on an earlier draft of this paper. 


\section{Introduction}

This paper focuses on the gender that is assigned to English nouns when they are borrowed into

a gendered language. More specifically, we analyze the factors that govern gender assignment

to anglicisms in Dutch. Our analysis will indicate that variation occurs when gender is assigned

to these nouns: language users do not necessarily agree with each other about the gender they

assign to a borrowed noun. Furthermore, we discuss in which conditions the amount of gender

variation is larger or smaller.

This paper is structured in the following way. Section 2 provides an overview of previous studies

on gender assignment to anglicisms. First, some universalities that have been identified in

previous research are outlined. Then, the notion of gender variation is introduced. In section 3 ,

the gender system of Dutch is discussed. First, the gender system that applies to native nouns is

described. Then, an overview of previous research into gender assignment to anglicisms in

Dutch is provided. Section 4 discusses the questionnaire that was used for the analysis, the

factors that were taken into account and the methodology of the study. Section 5 inquires into

the factors that influence the choice for a common or neuter article for an anglicism in Dutch.

Furthermore, the amount of agreement between the respondents regarding this choice is 
analyzed. Section 6 outlines the conclusions that can be drawn on the basis of this analysis, the shortcomings of the present study and suggestions for further research.

\section{Gender assignment to loanwords}

\subsection{Universalities in gender assignment to loanwords}

Gender assignment to non-native nouns has been studied in the context of lexical borrowing and against the background of bilingualism. Previous studies on this topic generally start from a set of anglicisms and their gender in a corpus, questionnaire or dictionary (e.g. Budzhak-Jones, 1997; Chirsheva, 2009; De La Cruz Cabanillas, Tejedor Martínez, Díez Prados, \& Cerdá Redondo, 2007; Poplack, Pousada, \& Sankoff, 1982; Smead, 2000; Thornton, 2009; ViolinWigent, 2006). Most of these studies rely on raw frequencies or proportions to determine the relative importance of the factors that influence gender assignment.

In general, it is assumed that the gender system of native nouns applies to loanwords as well, possibly amplified with some loanword-specific additional rules (Corbett, 1991, 2014). As described in Onysko (2007, p. 164), Family, for instance, is a feminine word in German, because of a native semantic rule that causes collectives of individuals to receive feminine gender (e.g. die Gruppe 'group', die Regierung 'government'). 
Determinants of gender assignment that do not apply to native nouns have been distinguished as well. First, some scholars have used semantic analogy as an explanation for gender assignment (e.g. Corbett, 1991; Poplack et al., 1982; Thornton, 2009): anglicisms can receive a specific gender due to a semantic association with a native noun in the host language (this factor is also referred to as 'lexical equivalence', 'lexical analogy' or 'lexical-semantic equivalence').

More specifically, a certain gender is assigned to a loanword, because a cognate or a translation equivalent in the receptor language has that gender as well. In a corpus of English computer terms borrowed into Spanish, for instance, De La Cruz Cabanillas et al. (2007) find that, although most anglicisms get masculine gender in Spanish, URL is probably feminine due to its association with the native feminine noun dirección ('address').

However, the semantic analogy explanation has received some criticism (Berteloot \& Van der Sijs, 2003; Corbett, 1991; Onysko, Callies, \& Ogiermann, 2013; Onysko, 2007). First, some scholars note that this kind of equivalence can often also be explained by an underlying semantic gender association that is applicable to native nouns in the host language as well (Corbett, 1991; Onysko, 2007). Second, determining the closest native equivalent is often problematic. Onysko (2007, pp. 166-167; pp. 327-328), for instance, finds that only 17 out of 63 monosyllabic masculine anglicisms have the same gender as their native German equivalent 
nouns (e.g. der Beat like der Schlag or der Takt), while for 18 out of the 63, the gender of the native equivalent is not masculine (e.g. der Song, in contrast to das Lied). The rest of the 63 monosyllabic masculine anglicisms in his corpus either have no clear German equivalent (e.g. der Flow), or can take more than one native equivalent, with different genders (e.g. der Chip like der Jeton, but also die Marke). Onysko et al. (2013, pp. 108-109) instead argue for an interpretation of lexical equivalence as a continuum of associative strength. This continuum can be interpreted in a quantitative way: the higher the associative strength between an anglicism and a native noun, the more likely it is that the anglicism will take the gender of the associated native noun. The association between an anglicism and a native noun is the strongest when the native language has a cognate that resembles the anglicism in (etymological) form and meaning (e.g. das Notebook analogous to German das Buch 'the book'). The lowest degree of associative strength occurs when the native language has a set of translational equivalents that are not formally related to the English noun (e.g. die E-Mail analogous to die elektronische Post). A transitional zone in the continuum is taken up by anglicisms that can be associated with a native basic concept for which only one native lexical item occurs (e.g. die Time like die Zeit). A second factor that influences gender assignment to loanwords is that anglicisms can also receive the unmarked or default gender of the host language. The unmarked gender is often 
equated with the most frequent gender in the host language, but prudence is in order. According to Corbett (1991), for instance, attributing default status to the most frequent gender class can mask aspects of the underlying gender system of the receptor language in loanword research. In Russian, for instance, the proportion of masculine nouns is exceptionally large for German neologisms (78.5\% of all German loanwords are masculine gender). Furthermore, masculine gender seems to be the default gender in Russian: the proportion of neuter gender native nouns is decreasing over time in favor of masculine (and feminine) gender nouns. However, Corbett argues that using unmarked gender as an explanation of gender assignment in this case conceals constraints that occur in the host language (see also Poplack et al., 1982). In fact, the large proportion of German loans that receive masculine gender can be explained by the fact that in German, many nouns end in a consonant. These types of nouns always receive masculine gender in Russian. 
Third, some scholars argue that the grammatical gender of a noun in the donor language may play a role as well (Corbett, 1991; Rothe, 2014). However, since in English, nouns do not carry overt gender markers ${ }^{1}$, this rule does not apply to anglicisms.

This study focuses on the assignment of gender to nominal anglicisms in a gendered language,

Dutch. In the native gender system of the Dutch language, the gender of nouns is to a large extent arbitrary. As a result, the influence of factors that do not apply to native nouns may be especially large.

\subsection{Variation in the amount of homogeneity in the speech community}

The approaches mentioned above presume stability in the gender of loanwords (see for instance Corbett, 1991). Variation in gender assignment to loanwords has usually been explained by the fact that the borrowed nouns are not yet established in the receptor language. For instance, although Poplack, Pousada \& Sankoff (1982) find some variation in their corpora, which are used to study the gender of anglicisms in Puerto Rican Spanish and Montreal French, they explain it by referring to the role of the speech community: "[o]nce a borrowed noun is assigned a gender by whatever criteria, there is generally unanimous agreement among speakers"

\footnotetext{
1 Some third person pronouns and $w h$-pronouns show gender distinctions (Biber, Johansson, Leech, Conrad, \& Finegan, 1999; Quirk, Greenbaum, Leech, \& Svartvik, 1985)
} 
(Poplack et al., 1982, 25). A study by Callies, Onysko \& Ogiermann (2012) explicitly pays attention to variability in the gender of anglicisms in German. The analysis shows that the amount of variation is relatively large, especially in experimental data. As a result, since most studies on gender assignment have relied on corpus data, it may be the case that the amount of variability in the gender of loanwords has been underestimated.

This paper aims to tackle these issues in two ways. First, in line with the results of Callies et al. (2012), the dataset that is used for the analysis is based on experimental data, collected on the basis of a forced choice task, to avoid diminishing the amount of variability in the speech community. Second, we empirically investigate the assumption of Poplack et al. (1982) that the gender of a loanword is variable until the noun is established in the receptor language by including two types of anglicisms in our dataset. On the one hand, we take into account established anglicisms, which are "widespread, recurrent and accepted" (Rothe, 2014, p. 209; also see Muysken, 2000). More specifically, we use English nouns that were borrowed in the 1950s or later, but that are already listed (with a particular gender) in a dictionary of the receptor language. We also incorporate non-established anglicisms in our dataset, which are English loans that are not dictionary-listed and not widespread. We also make sure to include nonestablished anglicisms with varying frequencies. This strategy allows us to empirically assess 
whether there really is "unanimous agreement among speakers" (Poplack et al., 1982, p. 25) once an anglicism has received a particular gender in the speech community.

Furthermore, we analyze gender assignment to anglicisms in Dutch in a quantitative way. We explicitly also examine whether statistical differences between established and non-established anglicisms are found. Moreover, we aim to add some methodological innovations to this field of study by relying on inferential statistical techniques rather than on raw frequencies or proportions. Additionally, we use the predictions of our quantitative analysis to empirically investigate the importance of the establishment of an anglicism for variability in the homogeneity in the speech community. Before presenting our analysis, we first discuss the native gender system of Dutch and some previous research on the gender of anglicisms in Dutch.

\section{Gender in Dutch}

\subsection{The gender system of native nouns in Dutch}

The gender of nouns in Dutch is largely arbitrary (Haeseryn, Romijn, Geerts, De Rooij, \& Van den Toorn, 1997). For most nouns in Standard Dutch, gender is not distinguishable on the basis 
of properties of the nouns themselves. Only for a small group of nouns, some formal ${ }^{2}$ or

semantic $^{3}$ tendencies have been described. The definite article identifies the gender of a noun:

nouns that receive de are common gender (e.g. de stoe/'the chair'), while het is used for neuter

nouns (e.g. het huis 'the house').

\begin{tabular}{llll}
\hline \hline & & common & neuter \\
\hline \hline definite article & & de & het \\
\hline attributive adj. in indefinite NP & $-e$ & $\varnothing$ \\
\hline demonstrative & proximal & deze & dit \\
\cline { 2 - 4 } pronoun & distal & die & dat \\
\hline relative pronoun & & die & dat \\
\hline third person & nominative & hij (masc.) / zij (fem.) & het \\
\cline { 2 - 5 } personal pron. & oblique & hem (masc.) / haar (fem.) & het \\
\hline possessive pronoun & zijn (masc.) / haar (fem.) & zijn \\
\hline \hline
\end{tabular}

Table 1: gender in Dutch in the singular noun phrase

2 The gender of a small group of nouns can be determined on the basis of formal properties of the noun itself (Haeseryn et al., 1997). Nouns ending in suffixes such as -de, -te, -heid, -ij, -ing, -nis and -st, for instance, are usually combined with de, while nouns ending in the diminutive suffix (-je and formal variants $-k j e,-p j e,-t j e$ and -etje) are always neuter.

3 The gender of a small number of nouns can be predicted on the basis of semantic properties (Haeseryn et al., 1997). Most names of people, animals, flowers, trees, fruits, seasons, numbers, sounds, letters, musical notes and some musical instruments are common gender. Names for the cardinal points, metals, languages, sports and games and cities and countries are neuter gender. 
Other features of the noun phrase, such as the attributive adjective, the third person personal pronoun and the demonstrative pronoun, can mirror the gender of a noun as well (Table 1). ${ }^{4}$ Interestingly, the personal and possessive pronoun still reflect the traditional three-way division into masculine, feminine and neuter gender. However, due to the loss of formal gender marking on the noun, the pronominal gender system shows variation (De Vogelaer \& De Sutter, 2011; Kraaikamp, 2012; also see Audring, 2009).

The Dutch language offers an interesting perspective on gender assignment to anglicisms. Most scholars assume that the native gender system is reflected in gender assignment to loanwords as well (see 2.1). As the gender system of native Dutch nouns is arbitrary to a large extent and currently undergoing variation, it is expected that non-native factors, like semantic analogy and the use of the default gender, will turn out to be important.

\subsection{The gender of anglicisms in Dutch}

Previous research on the gender of anglicisms in Dutch indicates that the most important tendency of gender assignment to anglicisms is that these nouns are assigned common gender, unless there is a reason for using neuter (Berteloot \& Van der Sijs, 2003; Geerts, 1996;

\footnotetext{
4 Gender is not marked on the plural forms of articles, attributive adjectives or pronouns.
} 
Haeseryn et al., 1997; Hamans, 2009; Koenen \& Smits, 1992; Posthumus, 1996; Schenck, 1985; Verhoeven \& Jansen, 1996). Such reasons can be semantic, morphological, or based on analogy with an element of the host language.

First, some anglicisms are assigned common or neuter gender because they fit into a specific semantic field. Breeds of dogs, for instance, like bulldog or huskey and drinks like gin, tonic or whiskey are common gender, while collectives like pane/ or team and sports like rugby or hockey $y^{5}$ re neuter gender nouns in Dutch. Some substances like plastic or velvet are neuter gender, while others can take common gender as well (e.g. de/het nylon, de/het rubber).

Second, the morphology of the anglicism can also play a role. More specifically, suffixes can influence the gender of a loanword, especially when the foreign suffix resembles a native suffix. For instance, nouns ending in -ing, like dancing, generally get common gender (like Dutch de mededeling 'announcement'), while nouns with suffix -ment, like management, are usually neuter gender (like Dutch het argument 'argument', het document 'document').

Third, it has been noticed that many anglicisms in Dutch copy the gender of a closely related equivalent (semantic analogy). In some cases, the equivalent is a cognate, which is both

\footnotetext{
5 Sport terms occasionally occur with a common gender definite article as well in colloquial language.
} 
formally and semantically related. For instance, arthouse probably takes neuter gender under the influence of its neuter cognate huis 'house', copyright is probably neuter under the influence of neuter gender recht 'justice, law'. The gender of other anglicisms is said to be influenced by the gender of a translational equivalent, which does not formally resemble the borrowed noun. For example, approach is possibly common gender because of an analogy with the Dutch common gender noun aanpak, whereas bacon may be neuter gender, because it can be associated with the native Dutch neuter noun spek.

However, it is not very clear how these rules interact. Most scholars merely provide an overview of all the rules that are applicable to anglicisms in Dutch on the basis of a list of examples of English loans that fit in well with one (or more) of the rules. Geerts (1996) is one notable exception: he constructs a hierarchy that describes what happens if multiple rules are applicable to a single anglicism in Dutch. According to Geerts, the gender of a cognate has a stronger influence than the prototypical gender for a semantic field, which in turn has a stronger influence than a suffix gender, which is again more important than a translation equivalent's gender. For 
instance, for gingerbeer, a neuter noun in Dutch, the association with the native neuter cognate bier $^{6}$ takes precedence over the prototypical common gender for the semantic field of drinks.

\section{Data and methods}

Our analysis aims to answer two distinct research questions. First, we use inferential statistical techniques to determine which factors have a significant influence on the gender that is chosen for anglicisms in Dutch. Second, we use the results of this analysis to examine in which cases homogeneity in the speech community, i.e. agreement or disagreement between the respondents of our survey per anglicism, is the smallest. To explore these research questions, we use data that were collected through a questionnaire. The analyses were carried out with $R$ (R. Development Core Team, 2009).

This section presents the data, variables and methodology that were used in the analyses.

Section 4.1 outlines the design of the questionnaire that was distributed. Section 4.2 provides an overview of the variables that were used for the analysis. In section 4.3 , the methodology is explained.

${ }^{6}$ Bier is a cognate of the head of the compound (beer). In Dutch, the head of a compound is usually the rightmost element of the word. 


\subsection{Data collection}

We distributed a questionnaire among 45 students from the University of Leuven. The questionnaire consisted of two parts. The first part contained a forced choice task, in which 175 sentences were presented to the respondents, with one nominal anglicism per sentence (Figure 1). The 175 anglicisms in the study represent combinations of a range of predictors that will be discussed in 4.2. Participants were asked to choose the definite article (common de or neuter het) and personal pronoun (masculine hij, feminine ze or neuter het ${ }^{7}$ that they would use to refer to the anglicism (marked in bold) in the sentence. They could also check a box labeled $/ k$ ken dit woord niet 'I don't know this word' in case they did not know the anglicism in question.

(De / Het) facelift voor de oude dreef gaat deze week van start. (Hij / Ze / Het) moet ervoor zorgen dat het aangenamer vertoeven is in en rond het stadsbos.

$\square$ Ik ken dit woord niet.

'The facelift of the old avenue starts this week. It has to ensure that it will be more pleasant in and around the town woods.'

Figure 1: excerpt of the main section (part 1) of the questionnaire

\footnotetext{
7 The analysis of the personal pronouns is discussed in a separate contribution by the authors. In $67.14 \%$ of the cases, there is grammatical agreement between the gender of the personal pronoun and the gender of the definite article. Preliminary analyses indicate that the factors that have the largest effect on the pronominal gender of the anglicism, are the article that is chosen for the anglicism and the animacy of the noun.
} 
We collected the nominal anglicisms that were used in the questionnaire in two ways. The established loanwords were collected by selecting nouns with an English etymology that were borrowed in 1950 or later from the fourteenth edition of Van Dale, an important descriptive dictionary of Dutch (Den Boon \& Geeraerts, 2008). Our final dataset contains 97 established anglicisms.

The second group consists of frequent non-established English nouns that were collected using both Dutch and English sources. As Dutch has two national varieties, Netherlandic Dutch and Belgian Dutch, and is considered a pluricentric language (Clyne, 1992), we used two news corpora that respectively represent one of the national varieties of Dutch: the Twente News Corpus ( TwNC) and the Leuven News Corpus (LeNC). TwNC contains all the newspaper articles that appeared in the five national daily newspapers from the Netherlands from 1999 to 2002. $L e N C$ is a corpus of national daily newspapers from Flanders. It contains all the newspaper data from 1999 to 2005. Together, $T w N C$ and $L e N C$ contain over 1.6 billion words. The non-established anglicisms were collected by first matching all the lexemes from English WordNet to token frequency lists of both corpora (see Zenner, Speelman, \& Geeraerts, 2012; Zenner, 2013). Ambiguous items like cognates (e.g. man), items with unclear etymology (e.g. 
supervisor) and loans from other languages (e.g. minister) were removed from this list. Next, a manual search was conducted in the Van Dale dictionary for entries with an etymological link to English to ensure that the anglicisms were not established in Dutch. Finally, we restricted our attention to relatively frequent non-established anglicisms: only anglicisms that occur with at least 100 tokens in TwNC and $\angle E N C$ combined and that are not listed in the fourteenth edition of Van Dale were included in the questionnaire. In total, our questionnaire contains 78 nonestablished anglicisms.

For drafting the stimulus sentences, we used a search engine (google.be) and a news website (mediargus.be) $^{8}$. Using these sources ensures that the sentences for the questionnaire are as natural as possible. We presented the sentences to our respondents in two random orders. A chi-square test indicates that there is no significant difference between the answers of the respondents in the two randomizations.

In the second part of the questionnaire, respondents filled out information such as their age, gender, place of residence, branch of study and the profession of their parents. Overall, 45

8 mediargus.be is an up-to-date collection of all Flemish newspapers and various critical Flemish magazines. It has been replaced by gopress.be since the distribution of the questionnaire. 
respondents participated in filling in the questionnaire. All 45 respondents ${ }^{9}$ were students at the University of Leuven at the time the questionnaire was distributed (April/May 2013). Their mean age is 21.49 . Men are underrepresented in our data (10 male respondents out of 45$)$. The respondents come from all over Flanders: 24 respondents live in the provinces of Antwerp and Flemish Brabant (central region of Flanders), 13 in the province of Limburg (in the eastern region of Flanders) and 8 in the provinces of East or West Flanders (in the western region of Flanders). We use the profession of their parents as a proxy for the socio-economic status of the participants. More specifically, we rely on the Standaard Beroepen Classificatie 'standard classification of professions' of the Dutch Central Bureau of Statistics (Centraal Bureau voor de Statistiek, 2010).

946 students participated to the questionnaire, but we excluded one respondent from the analysis, because the person in question was much older than the other participants in our study (67 y.o.., while other participants are between 19 and 25 y.o.). 


\subsection{Variables ${ }^{10}$}

In this section, we present the factors, distinguished on the basis of previous research, which may influence gender assignment to loanwords in Dutch. These factors will be used as the independent variables for a logistic regression analysis. A few theoretically interesting predictors, such as the presence of a suffix and the gender that is associated with a suffix were not included in the analysis. Determining the influence of the gender associated with a suffix is, for instance, relatively difficult in a multifactorial setting, because most suffixes that are used for words borrowed from English are generally associated with common gender in Dutch (one exception is the suffix - ment).

\subsubsection{Establishment}

The first predictor we include in the analysis describes information regarding the establishment of the anglicism in the Dutch language. The degree of establishment of an anglicism is

10 The questionnaire was constructed in such a way that the degree of individuation (animate, count/mass noun, concrete/abstract noun), a factor that is especially important for pronominal gender assignment, could easily be tested, because we assumed that this factor might influence the adnominal gender of loanwords as well. However, for the articles, initial analyses showed that this factor is not as important and that other variables, namely those that are discussed in this section, have a larger influence on the article that is used for an anglicism. Since some of these variables were only added to the dataset after the questionnaire was circulated, the data is not distributed among the levels of the predictors in a completely homogeneous way. 
determined on the basis of two measures. On the one hand, we use frequency information to distinguish between more and less frequent non-established anglicisms. On the other hand, we use the gender that is listed in the dictionary for the established nouns. The levels of this variable are visualized in Table 2.

\begin{tabular}{l|l|l|l}
\hline \hline \multicolumn{2}{l|}{ non-established anglicisms } & \multicolumn{2}{|l}{ established anglicisms } \\
\hline \hline \multirow{2}{*}{ frequency } & frequent & established & de \\
& infrequent & gender & het \\
\hline \hline
\end{tabular}

Table 2: levels of predictor establishment

In Section 4.1, the different data collection methods for the established and non-established anglicisms were discussed. The frequency value of the non-established anglicisms is based on their token counts in $T w N C$ and $L e N C$, with frequent nouns occurring 300 times and more in $T w N C$ and $L e N C$ combined, and infrequent non-established anglicisms occurring less than 300 times (see Appendix $2^{11}$ ). With regard to the established nouns, we follow the information listed in the Van Dale dictionary: anglicisms that are listed as common nouns are coded as established

\footnotetext{
${ }^{11}$ An anonymous reviewer points out that a larger margin between the categories of frequent and infrequent anglicisms could provide more insight into the effect of the frequency of an anglicism, because nouns that occur only slightly less than 300 times are categorized differently from nouns that occur only slightly more than 300 times. However, re-running the analysis without the nouns with a token frequency close to 300 (viz. nouns that occur between 200 and 400 times) does not cause any major differences in the analysis: the same variables reach significance and the coefficients for the mixed model are almost identical to the coefficients of the model that does include these anglicisms (see 5.1).
} 
$d e$, while anglicisms that are listed as neuter nouns are classified as established het (see Appendix 1).

The frequency of non-established anglicisms and the gender listed for established anglicisms are combined in one composite variable establishment. This categorical variable has four possible levels: 'established de', 'established het', 'non-established frequent', 'non-established infrequent'. Table 3 provides an overview of the frequency of the four types of anglicisms in the questionnaire (i.e. the number of sentences the anglicism occurs in) and examples of anglicisms for all of the levels. Appendices 1 and 2 contain a list of all the nouns in the questionnaire. For the established nouns, the gender that is listed in the Van Dale dictionary is specified. For the non-established noun, their token frequency in $T w N C$ and $L e N C$ and the categorical division into frequent and infrequent anglicisms, is provided.

We expect that respondents frequently choose the gender that is listed in the dictionary for the established anglicisms, while they might often use the default article de for non-established nouns. Furthermore, utilizing this variable allows us to inquire into the importance of the establishment of an anglicism as an explanatory factor of variability in the amount of agreement 
in the speech community (see 2.2). We expect less homogeneity to show up for anglicisms that are not yet established and infrequent.

\begin{tabular}{|c|c|c|c|}
\hline & levels & $\begin{array}{l}\text { frequency in } \\
\text { questionnaire }\end{array}$ & examples \\
\hline \multirow{2}{*}{$\begin{array}{l}\text { established } \\
\text { anglicism }\end{array}$} & established de & 66 & blooper, loafer \\
\hline & established het & 12 & aquaplaning ${ }^{12}$, jack \\
\hline \multirow{2}{*}{$\begin{array}{l}\text { non-established } \\
\text { anglicism }\end{array}$} & non-established frequent & 49 & award, network \\
\hline & non-established infrequent & 48 & publicity, shareholder \\
\hline
\end{tabular}

Table 3: absolute frequencies of predictor establishment

\subsubsection{Article of lexical-semantic equivalent}

The variable article of lexical-semantic equivalent has two levels: de and het. This variable takes

two types of analogy into account: analogy with the gender of a Dutch cognate and analogy with

the gender of a Dutch translational equivalent. We define a cognate as a formally and

semantically associated word: Dutch kanaal, for instance, is a cognate lexeme of channel,

character is a cognate of the native noun karakter. A translational equivalent has a looser

\footnotetext{
12 Preliminary analyses indicated that established anglicisms that are listed with het and established anglicisms that are listed with both de and het behave similarly: the proportion of neuter responses is in both cases larger than for the nouns that are only listed with common gender. For this reason, established nouns that receive both common and neuter gender (e.g. aquaplaning) in Van Dale are coded as established het. Note that only four anglicisms in the dataset are listed with both common and neuter gender in the dictionary (see Appendix 1).
} 
connection with the anglicism: the Dutch noun does not bear any formal similarity to the borrowed noun. Prestatie, for example, is the translational equivalent of achievement and gastenverblijf is the translational equivalent of guesthouse (which also has a Dutch cognate, huis). To determine the most suitable translation, we use a translation dictionary (Van Dale Lexicografie, 2006).

Rather than using the presence or absence of a cognate or a translation as a predictor, we instead rely on the gender that is listed for that cognate or translation of an anglicism. The gender of the cognate or translation is based on the Van Dale dictionary (Den Boon \& Geeraerts, 2008) and the Woordenlijst Nederlandse Taal (Instituut voor Nederlandse Lexicologie \& Nederlandse Taalunie, 2005), which lists the official spelling and gender of a large number of Dutch words.

We expect that anglicisms will frequently adopt the gender of their Dutch lexical-semantic equivalent. Since initial analyses confirmed that, as indicated by Onysko et al. (2013), cognate gender is more influential as a source of gender analogy than the gender of a translation equivalent in the host language, we use a coding procedure for the lexical-semantic equivalence predictor that consists of two parts. As a first step, we check whether an anglicism has a clear 
cognate. If so, we code the gender of that cognate. If the anglicism does not have a clear cognate, we code the gender of the translational equivalent. ${ }^{13}$ Skateboard, for example, is translated with a common noun rol(schaats)plank in the dictionary, but it receives neuter gender het for article of lexical-semantic equivalent as bord is a neuter cognate. Beach does not have a clear cognate, so for article of lexical-semantic equivalent, it receives the neuter gender of its translation, strand. Table 4 provides an overview of the distribution of the article of lexicalsemantic equivalent predictor in the questionnaire. In general, anglicisms with a common gender equivalent (article de) are much more frequent than anglicisms with a neuter equivalent (article het).

13 Initially, anglicisms without a clear cognate and without a translational equivalent (e.g. aquaplaning), on the one hand, and nouns with cognates or translational equivalents that can get both common and neuter gender (e.g. busticket. both de ticket and het ticket are possible), on the other hand, formed a separate category in the analysis. However, as preliminary analyses indicated that the first group of nouns (no Dutch cognate or translation) behave similarly to the nouns with a common gender equivalent, we collapsed these groups of nouns into one category, de. Since for this group of nouns, there is no conflict with the default gender - common gender according to previous studies - we do not expect the gender of the Dutch equivalent to have a significant effect on the article that is chosen for this group of anglicisms. For two anglicisms in the dataset with equivalents that can take both common and neuter gender, preliminary analyses indicated that these nouns show the same behavior as the anglicisms with neuter gender equivalents. This is expected, because for these nouns, a conflict between the default gender and the equivalent's gender is possible. For this reason, we added these nouns to the group of anglicisms with a neuter equivalent. 


\begin{tabular}{lll}
\hline $\begin{array}{l}\text { article of lexical-semantic } \\
\text { equivalent }\end{array}$ & $\begin{array}{l}\text { frequency in } \\
\text { questionnaire }\end{array}$ & examples \\
\hline \hline de & 133 & $\begin{array}{l}\text { dancefloor (Dutch cognate: de dansvloer), } \\
\text { engine (Dutch translation: de motor) }\end{array}$ \\
\hline het & 42 & character (Dutch cognate: het karakter), \\
& & sound (Dutch translation: het geluid) \\
\hline \hline
\end{tabular}

Table 4: absolute frequencies of predictor article of lexical-semantic equivalent

\subsubsection{Animacy of the anglicism}

We also include semantic information about the anglicisms, because a small group of native

Dutch nouns receives a certain gender because of the semantic field to which they belong (see

3.1; Haeseryn et al., 1997). Names of people and animals, for instance, are generally common

gender (de onderwijzer 'the teacher', de leeuw'the lion'), while names of sports and games and

names of metals usually have neuter gender (het voetbal 'the soccer', het goud 'the gold').

However, with the exception of nouns referring to sports and games and person reference

nouns, most loanwords do not belong to these semantic categories. ${ }^{14}$ For instance, names of

trees (e.g. de berk 'the birch'), flowers (e.g. de lelie 'the lily') or seasons (de herfst 'the autumn'),

which are generally common gender, are probably not prone to borrowing. The same holds for

\footnotetext{
14 Two anglicisms belonging to the semantic classes that play a role in the native gender system are used in Dutch: indian summer (name of a season) and slang (name of a language).
} 
the names of metals (e.g. het goud 'the gold'), which usually receive neuter gender.

Consequently, we focus on the animacy of the anglicisms in the dataset to determine whether

animate loanwords show a preference for the common gender, as is the case for the native

Dutch nouns. ${ }^{15}$

An anglicism is coded as animate if the referent of the noun is human or an animal (e.g. believer,

bulldog). All other anglicisms are labeled 'inanimate' (e.g. busticket, container ship). Table 5

provides an overview of the absolute frequencies of the animacy predictor in the questionnaire.

Since native animate nouns are usually common gender, we expect animate anglicisms to occur

frequently with the common gender article de as well.

\begin{tabular}{lll}
\hline \hline animacy & frequency in questionnaire & examples \\
\hline \hline inanimate & 148 & facelift, reality \\
\hline animate & 27 & believer, nanny \\
\hline \hline
\end{tabular}

Table 5: absolute frequencies of predictor animacy

\footnotetext{
15 Alternative coding procedures that can reveal whether semantic features have an effect on the gender of anglicisms were tested as well. More specifically, the degree of individuation of the anglicism (animate, count/mass noun, concrete/abstract noun) was taken into account. Furthermore, we also coded each anglicism for the semantic fields that are applicable according to the Historical Thesaurus of the OED (HTOED; Oxford University Press, 2013). However, these operationalizations do not reach significance in a multifactorial environment.
} 


\subsubsection{Lectal features}

We took into account the influence of various lectal features on gender assignment to anglicisms in Dutch, using personal information about the participants that was collected in the second part of the questionnaire. More specifically, we verified whether the gender of the participants, their

\begin{tabular}{lll}
\hline \hline predictor & levels & number of respondents \\
\hline \hline gender of respondent & female & 35 \\
\cline { 2 - 3 } & male & 10 \\
\hline region & central region & 24 \\
\cline { 2 - 3 } & eastern region of Flanders & 13 \\
\cline { 2 - 3 } & western region of Flanders & 8 \\
\hline education parents & high & 27 \\
\cline { 2 - 3 } & low & 18 \\
\hline proficiency in English & good & 25 \\
\cline { 2 - 3 } & bad & 20 \\
\hline knowledge of local & no & 26 \\
\cline { 2 - 3 } dialect & yes & 19 \\
\hline \hline
\end{tabular}

Table 6: overview of lectal variables

place of residence, the educational background of their parents (as a proxy for the socio-

economic status of the participants) ${ }^{16}$, their degree of proficiency in English and their knowledge

\footnotetext{
${ }^{16}$ More specifically, we measured the educational background of the parents by calculating the maximum of the scores of required educational background for the professions of both parents in the Standaard Beroepen Classificatie ('Standard classification of professions') of the Dutch Central Bureau for Statistics
} 
of a local dialect cause differences in the responses (Table 6). Overall, the number of participants to the questionnaire is relatively low $(\mathrm{N}=45)$. This may explain why, as the analyses will show, none of the lectal features reach significance in a multifactorial environment.

\subsection{Methodology}

Previous research on gender assignment to anglicisms in Dutch relies on raw frequencies or proportions to determine the relative importance of the factors that influence gender assignment.

Moreover, these studies generally use small corpora or lists of anglicisms collected from dictionaries to establish a list of assignment rules (see for instance Geerts, 1996). We aim to complement these studies by using inferential statistics to examine which factors have a significant influence on the gender that is chosen. More specifically, we use multiple mixedeffects logistic regression to model the effect of lectal and language-internal features on the binary response variable article (common de or neuter het).

A major advantage of using a multifactorial regression model is that it can assess the impact and the significance of each of the predictors while taking into account the combined influence of all

(Centraal Bureau voor de Statistiek, 2010). This classification ranges from 0 (jobs requiring a lower level of education) to 8 (jobs requiring a higher level of education). If the maximum required educational level was larger than or equal to 6 , the participant's parents were coded as having a high educational background, if it was smaller than 6, their educational background was coded as not high. 
the variables in the model. Furthermore, the technique allows for the inclusion of random effects. Using random effects is appropriate when a factor cannot be replicated, in the sense that the levels of the factors are not fixed and would differ if the experiment would be repeated (Baayen, 2008). For a variable like gender, for instance, the levels (male, female) are the same every time an experiment is executed. The variables anglicism and respondent in our questionnaire, however, cannot be replicated: they are sampled from a large population of possible anglicisms and respondents. Moreover, each respondent in the dataset chose an article for 175 anglicisms. Accordingly, the dataset will contain some respondent-specific regularities: the responses of each respondent are probably correlated. The same holds for each of the anglicisms: 45 respondents chose an article for each of the English nouns, so the responses per anglicism are probably correlated. To cope with this type of respondent-specific and anglicism-specific variation that is not captured by the other predictors in the model, random factors can be included in a logistic regression model. 


\section{Determinants of gender assignment to anglicisms in Dutch}

This section inquires into the factors that influence the gender that is chosen to refer to an

anglicism in Dutch. Overall, the participants of the questionnaire show a preference for using the common gender article de (Table 7).

\begin{tabular}{lll}
\hline article & absolute frequency & relative frequency \\
\hline de & 6629 & $84.98 \%$ \\
\hline het & 1172 & $15.02 \%$ \\
\hline NA & 74 & $/$ \\
\hline \hline
\end{tabular}

Table 7: distribution of response variable article

\subsection{Predicting anglicism gender}

Using a forward stepwise selection procedure, we built a mixed-effects logistic regression model.

We examined the influence of all the variables discussed above, namely establishment, article of lexical-semantic equivalent and animacy of the anglicism, and the respondent-related features (gender, region, education level of the parents, proficiency in English and knowledge of a local dialect). Three predictors reach significance at the 0.05 level: establishment of the anglicism, 
animacy of the anglicism and article of lexical-semantic equivalent. ${ }^{17}$ Interaction effects were taken into consideration, but they did not contribute enough to the explanatory power of the model to be included in the final model. Our model also contains random intercepts for two factors: anglicism and respondent. We checked whether by-subject random slopes could be added to the model, but the data do not support a model that is more complex than the model with two random intercepts. Diagnostics reveal a good fit of our model to the data. ${ }^{18}$ The model performs well: it predicts $91.33 \%$ of the variants in our dataset correctly (compared to a baseline

\footnotetext{
17 First, a model containing only fixed effects was built, to assess the power and goodness of fit of the model. Five predictors reached significance in this model, but two predictors lost significance when the random factors were added to the model.

18 Initially, we confirmed that there were no harmful associations between all the predictors that were considered for the analysis. We assessed the goodness of fit of the fixed effects-only model in three ways: with an outlier analysis (no outliers were found), with a test for multicollinearity (all VIF-scores were below 2 , with VIF-scores larger than 4 pointing to harmful associations between predictors) and by calculating the overdispersion parameter (Faraway, 2006). This parameter is close to 1, which indicates that the residual deviance is approximately $X^{2}$ distributed with the appropriate degrees of freedom.

The diagnostics of the fixed effects-only model indicate that the power of the model is good. Pseudo $\mathrm{R}^{2}$, a value ranging between 0 and 1 , is 0.286 , which indicates a decent fit for a logistic model. The $\mathrm{C}$-value, which also ranges between 0 and 1 , is 0.804 , indicating predictability. With regard to the random effects structure of our model, we checked whether the Best Linear Unbiased Predictors (BLUPs) are normally distributed. Although a Shapiro-Wilk test reaches significance $(p<0.01)$ for both of our random effects, which indicates that the BLUPs are not normally distributed, we also inspect the distribution of the BLUPs visually and we conclude that the distribution is good enough to permit drawing conclusions on the basis of our mixed model. We also check whether including the fixed effects in our model ensures a decrease in standard deviation around the BLUPS. Standard deviation decreases with $28.58 \%$ for the two random effects combined, which indicates that the model with the random factors has a better fit than a model that only includes fixed effects.
} 
of $85 \%$ for a model that always chooses the most frequent variant $d e$ ). The model's performance is also confirmed by the high C-value of 0.93 (a C-value of 0.8 or higher indicates that the model has predictive power).

Table 8 presents the output for the fixed effects in the mixed model. The predictors are presented in the table in their relative order of importance: the article of the lexical-semantic equivalent and the degree of establishment of the anglicism have a large influence on the choice between de and het for an anglicism. Animacy does not influence the alternation as much as the other two variables.

One reference level is chosen for each of the variables in the model. This level is included in the intercept and, hence, does not receive separate values in the output. For instance, the reference level for article of lexical-semantic equivalent is de. The estimates, which are shown in the second column of the table, convey the direction and effect size of the impact of each predictor. These estimates for the levels of each predictor should be compared to the estimate for the intercept. The final column reports the $p$-value for each of the estimates (alpha level $=0.05$ ). The model predicts het, which means that positive estimates with a p-value smaller than 0.05 indicate that the odds of respondents choosing het are higher in comparison to the reference 
level, while significant negative estimates indicate that the probability of respondents choosing $d e$ is higher in comparison to the reference level.

\begin{tabular}{|c|c|c|c|c|}
\hline predictor & estimate & Std. Error & z-value & p-value \\
\hline (Intercept) & -6.5453 & 0.5620 & -11.646 & 0 \\
\hline \multicolumn{5}{|l|}{ article of lexical-semantic equivalent } \\
\hline \multicolumn{5}{|l|}{ reference level: de } \\
\hline het & 1.9898 & 0.3436 & 5.791 & 0 \\
\hline \multicolumn{5}{|l|}{ establishment } \\
\hline \multicolumn{5}{|l|}{ reference level: established de } \\
\hline established het & 3.2649 & 0.5933 & 5.503 & 0 \\
\hline non-established frequent & 0.6445 & 0.3776 & 1.707 & 0.0879 \\
\hline non-established infrequent & 1.2088 & 0.3725 & 3.245 & 0.0012 \\
\hline \multicolumn{5}{|l|}{ animacy } \\
\hline \multicolumn{5}{|l|}{ reference level: animate } \\
\hline inanimate & 2.5290 & 0.5259 & 4.809 & 0 \\
\hline
\end{tabular}

Table 8: output for the fixed effects in the mixed effects logistic regression model. Alpha $=0.05$. Positive estimates indicate a higher probability of het, negative estimates indicate a higher probability of de.

Table 8 shows that, not surprisingly, the gender of a Dutch cognate or translation equivalent often correlates with the gender that is assigned to an anglicism. More specifically, the chance of respondents using het is significantly higher when the Dutch lexical-semantic equivalent of the anglicism has het as its article, in comparison to anglicisms with a common gender Dutch equivalent. For example, only 1 out of 45 respondents uses de for skateboard, which has a clear 
neuter cognate het bord, whereas for input, which has a common gender translation, de invoer, 44 out of 45 respondents select de.

Second, concerning the establishment of the anglicisms in the questionnaire, Table 8 confirms that the gender that is assigned to established anglicisms in the dictionary is a significant predictor of gender assignment. The probability of respondents using het is much higher if the anglicism receives het in the dictionary (e.g. 31 out of 45 respondents use het for entertainment) than when the anglicism is listed as a common noun with de (e.g. only 1 out of 45 respondents uses hetfor knowhow). Furthermore, Table 8 also reveals that significant differences between loanwords that are established and listed with de, and non-established anglicisms occur: the probability of using de is smaller for non-established anglicisms, especially if they are infrequent. This probably has to do with the fact that there is a strong correlation between established nouns that are listed with de and usage of the common gender determiner. For non-established anglicisms, such a correlation does not exist.

The estimates for the third factor in the model indicate that respondents are more inclined to use the neuter article het for inanimate nouns. This is in accordance with the general agreement 
system of Dutch, as described in Haeseryn et al. (1997): nouns referring to humans and animals are generally common nouns.

In sum, the analysis indicates that anglicisms generally receive the common gender article de in Dutch, but the chance of using het increases in specific cases. More specifically, when the anglicism has a neuter gender cognate or translational equivalent in Dutch, when the anglicism is established and listed with neuter gender in the dictionary or non-established and infrequent, and when the anglicism is inanimate, the odds of using het are significantly larger.

Interpreting the output for the random effects that are included in the model, viz. anglicism and respondent, offers some further insight into the structure of the variation that is found in the data set. Table 9 provides an overview of the variance and standard deviation associated with the random factors (both adjustments to the intercept) in the model. The reported variances reflect the importance of the random effects. Most of the variation is accounted for by by-item intercept adjustments.

Examining the random intercepts reveals that the highest positive adjustment are made for the anglicisms character (4.55) and shoppingcenter (3.97). This means that, all other things being equal, a neuter gender article is used for these nouns exceptionally frequently. The highest 
negative adjustments are associated with baseballbat (-3.32) and countdown (-3.20). For these nouns, common gender de is favored. Some by-subject variation occurs in the dataset as well. The intercept adjustments indicate that two respondents, with ID's 13 (2.22) and 36 (2.10), select the neuter gender het much more frequently than the other respondents, all other things being equal. Both of these respondents are 21 year old women, but they do not have any other socio-economic features in common. The largest negative intercept adjustments are made for respondents $3(-1.15)$ and $17(-0.75)$. However, the difference with the other subjects is not very large.

\begin{tabular}{lll}
\hline \hline random effect (intercept adjustments) & variance & sd \\
\hline \hline anglicism & 2.8546 & 1.6895 \\
\hline respondent & 0.5385 & 0.7339 \\
\hline
\end{tabular}

Table 9: variance and standard deviation of the random factors in the regression model

\section{2. (Dis)agreement between respondents: analysis and results}

In this section, we examine the extent to which the respondents that participated to the questionnaire, agree or disagree with each other regarding the article that they assign to an anglicism. As the discussion of the random factors in the regression model indicated, most of the variation is explained by by-item intercept adjustments. By-subject intercept 


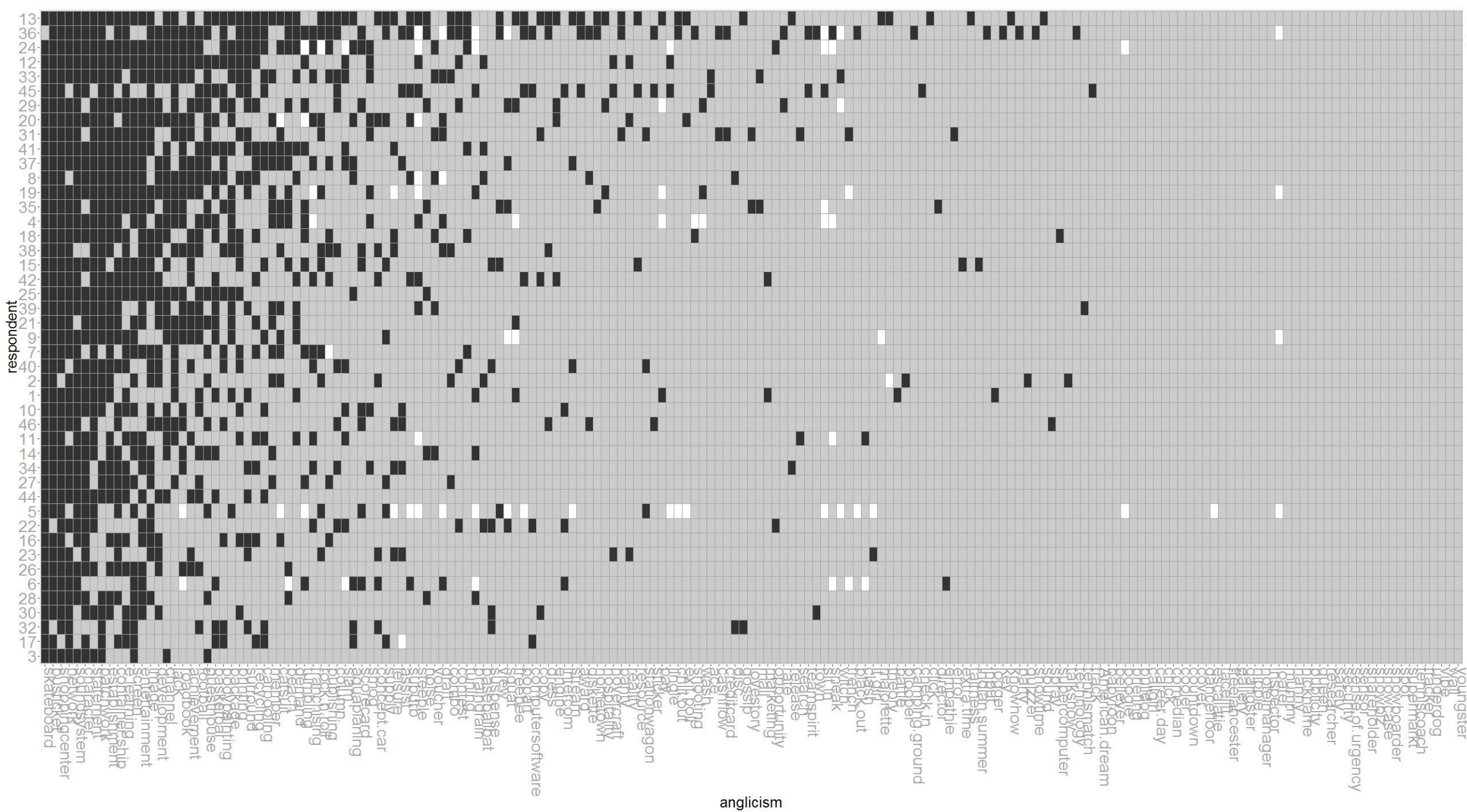

Figure 2: plot of article chosen per anglicism and per respondent 
adjustments contribute significantly to the model as well, which means that the respondents do not always agree with each other about the gender that they assign to a particular anglicism.

Figure 2 provides a visualization of the variation in our dataset per anglicism and per respondent. In the plot, a grey box indicates that the respondent selected de, a black box indicates that the respondent chose het, while a white box represents a missing value. For example, respondent 12 chose het for the anglicism jingle, while respondent 22 selected de for this noun. Respondents 5 and 24 did not make any selection. For computersoftware, respondent 17 selected het, while respondent 27 chose de. The anglicisms are ordered (on the x-axis) by decreasing proportion of het responses from left to right. The respondents are ordered (on the yaxis) by decreasing proportion of het responses from top to bottom.

The picture reveals that the proportion of neuter (or common) gender responses differs greatly per respondent and per anglicism. Respondent 3 chooses het the least (for 11 out of 145 anglicisms), while respondent 13 chooses het most frequently (for 66 out of 145 anglicisms). All respondents but one select het for skateboard, while for a relatively high number of anglicisms, on the right-hand side of the plot, all respondents choose the same article (youngster, wall, vibe etc.). Interestingly, for none of the anglicisms in the dataset, all respondents select het. 
Furthermore, the plot corroborates the finding that within-respondent variation occurs in the dataset as well, in the sense that respondents do not systematically opt for the same article for two anglicisms with similar properties. For instance, respondent 36 assigns the neuter article het to teamspirit, an inanimate, non-established frequent anglicism with a common gender Dutch cognate (spirit), while the same participant assigns the common article de to a similar anglicism, (American) dream $^{19}$ (also inanimate, non-established, frequent and with a common gender Dutch cognate, droom).

Crucially, Figure 2 also reveals variation in the amount of disagreement between the respondents in the dataset per anglicism. For some anglicisms, like skateboard, or youngster, wall and vibe, all or most of the respondents agree with each other about the appropriate gender, but for other anglicisms, there is more variation. For the fitness term, squat, for instance, about $85 \%(38 / 45)$ of the respondents choose the same article, de; for franchising, about $71 \%$ $(32 / 45)$ of the respondents agree on de; for achievement, there is very little agreement: 22 respondents select de, and 23 respondents select het.

\footnotetext{
19 Some of the anglicisms appeared with an English modifier in the questionnaire because the nouns only appeared in certain collocations in the sources that were consulted (see 4.2.1): American dream, camping

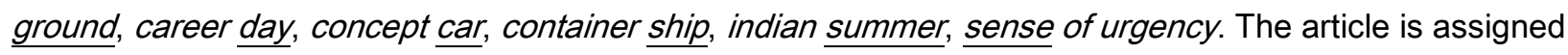
to the underlined head nouns in each of these multi-word expressions.
} 
By relying on the predicted probabilities of the regression model, we can determine whether the amount of variation that occurs for the anglicisms in the dataset is influenced by the predictors that have been discussed in Section 4.2. More specifically, for each combination of the variables that was included in the questionnaire, we predict the probability of the respondents selecting het. If this probability is close to $50 \%$, the amount of disagreement is the highest. If it is close to $0 \%$ or $100 \%$, respondents agree with each other more (they either all choose de, or all choose het).

Table 10 presents an overview of all the combinations of the levels of the predictors that occur in the dataset. Columns 2, 3 and 4 show the level that is used per predictor. Columns 5 and 6 show the mean predicted probability of het and the standard deviation for that combination of levels. Columns 7 and 8 indicate how many records are available for the combination of predictors.

The table shows that the probability of using het is never higher than $65 \%$. Furthermore, the table indicates that respondents seem to disagree with each other the most (i.e. the mean predicted probability of het is close to $50 \%$ ) when a conflict arises between different factors that influence the gender that is assigned to an anglicism. This is apparent in three sets of cases. 


\begin{tabular}{|c|c|c|c|c|c|c|c|}
\hline & $\begin{array}{c}\text { article of } \\
\text { equivalent }\end{array}$ & establishment & animacy & $\begin{array}{c}\text { mean } \\
\text { predicted } \\
\text { probability }\end{array}$ & $\begin{array}{c}\text { sd } \\
\text { predicted } \\
\text { probability }\end{array}$ & $\begin{array}{c}\text { total } \\
\text { number of } \\
\text { records }\end{array}$ & $\begin{array}{c}\text { number of } \\
\text { anglicisms in } \\
\text { questionnaire }\end{array}$ \\
\hline 1 & de & established de & animate & 0.0024 & 0.0044 & 495 & 11 \\
\hline 2 & het & established de & animate & 0.011 & 0.0151 & 135 & 3 \\
\hline 3 & de & $\begin{array}{c}\text { non-established } \\
\text { frequent }\end{array}$ & animate & 0.0062 & 0.0097 & 270 & 6 \\
\hline 4 & de & $\begin{array}{c}\text { non-established } \\
\text { infrequent }\end{array}$ & animate & 0.0087 & 0.0121 & 225 & 5 \\
\hline 5 & het & $\begin{array}{c}\text { non-established } \\
\text { infrequent }\end{array}$ & animate & 0.5288 & 0.2659 & 90 & 2 \\
\hline 6 & de & established de & inanimate & 0.0639 & 0.0932 & 1980 & 44 \\
\hline 7 & het & established de & inanimate & 0.0736 & 0.1082 & 360 & 8 \\
\hline 8 & de & established het & inanimate & 0.4687 & 0.3142 & 180 & 4 \\
\hline 9 & het & established het & inanimate & 0.6475 & 0.2752 & 360 & 8 \\
\hline 10 & de & $\begin{array}{c}\text { non-established } \\
\text { frequent }\end{array}$ & inanimate & 0.0783 & 0.1240 & 1440 & 32 \\
\hline 11 & het & $\begin{array}{c}\text { non-established } \\
\text { frequent }\end{array}$ & inanimate & 0.3862 & 0.3263 & 495 & 11 \\
\hline 12 & de & $\begin{array}{c}\text { non-established } \\
\text { infrequent }\end{array}$ & inanimate & 0.1146 & 0.1691 & 1395 & 31 \\
\hline 13 & het & $\begin{array}{c}\text { non-established } \\
\text { infrequent }\end{array}$ & inanimate & 0.4111 & 0.2724 & 450 & 10 \\
\hline
\end{tabular}

Table 10: predicted probabilities (for het) of each combination of predictors present in the dataset

First, it is close to $50 \%$ for twelve inanimate, established anglicisms that are listed with het (rows

8 and 9 in the table). The article of a Dutch equivalent only has a minor influence on these

nouns. However, it is noteworthy that even for established anglicisms for which there is no 
conflict between the neuter listed gender and the neuter gender of a Dutch equivalent, the probability of using het is still relatively low (64.75\%). This is especially clear when the predicted values for these nouns are compared to the predictions for inanimate established anglicisms that are listed with de and have a common gender equivalent (row 6). For these anglicisms, respondents agree with each other most of the time: the probability of using het is only $6.39 \%$. This difference can be explained by the fact that when properties that favor a neuter article are available, a conflict arises between these properties and the default article for anglicisms, de. Previous studies have argued that anglicisms get the common definite article de, unless there is a reason for using neuter gender het (see 3.2). However, our data indicate that, rather than respondents categorically selecting neuter gender in this case, the availability of a reason for using neuter gender het seems to cause a higher amount of disagreement.

A second set of cases in which the disagreement between respondents is relatively high, is for non-established anglicisms that have a neuter gender Dutch equivalent. If these nouns refer to an animate referent, the disagreement between respondents is the highest $(52.88 \%$ probability of choosing het). However, note that only two nouns in the questionnaire belong to this group. The findings for these nouns can be explained by the general semantic tendency in Dutch that names for people and animals are usually common gender. As a result, there is a conflict 
between the common gender that is often used for animate nouns and the neuter gender of the Dutch equivalent.

Third, it is unexpected that the proportion of using het is relatively low for the inanimate nonestablished nouns (38.62\% and $41.11 \%)$. The twenty-one nouns that belong to these groups are not influenced by any factors that favor common gender, while one neuter gender-favoring feature is available. Nevertheless, a lot of respondents rely on the default common gender article for this group of nouns.

In sum, these results seem to contradict the explanation often provided in the literature, that gender variation (i.e. disagreement in the speech community) only occurs for non-established nouns. In our data, variation occurs for established nouns as well, if they do not have the default gender listed in the dictionary. Consequently, establishment in the speech community does not serve as the sole explanation for an increase in homogeneity in our dataset. Furthermore, the analysis indicates that in the case of conflict between multiple factors that influence the gender of an anglicism, like a neuter lexical-semantic equivalent versus the default common gender, homogeneity decreases. Instead, conflicting factors seem to serve as explanations for more heterogeneity in the speech community. 


\section{Discussion and conclusion}

In this paper, we have focused on the gender that is assigned to anglicisms in Dutch. A number of hypotheses were raised on the basis of previous research. First, it is generally assumed that anglicisms follow the gender system that applies to native nouns as well. Second, it has been argued that semantic analogy and the default gender of the host language play a role in gender assignment to anglicisms. For anglicisms in Dutch, previous research suggests that anglicisms receive common gender $d e$, unless there is a reason for using neuter gender het. Such reasons can be semantic, morphological or analogy-based. However, with the exception of Geerts (1996), in which a hierarchy of rules is discussed, the interaction between these determinants of anglicism gender remains largely underspecified. Finally, scholars have argued that the gender of anglicisms is stable (but see Rothe, 2014). When variation occurs, the explanation that has been provided is that gender variation only occurs until the noun is established in the speech community.

This paper contributed to these findings by utilizing inferential statistics to investigate gender assignment to anglicisms in Dutch. First, we inquired into the factors that underlie the gender that is assigned to a nominal English loanword. Then, by relying on the predictions of the model 
that resulted from this analysis, variation in the amount of agreement between respondents was inspected more closely. Furthermore, since the data included both established and nonestablished borrowings, we were able to examine the influence of the degree of establishment of an anglicism.

The first part of our analysis confirms the importance of the common gender article de: only $15.02 \%$ of our data contain the neuter gender article het. The regression model provides further evidence for the importance of the gender system that applies to native nouns: for animate anglicisms, common gender de is generally used, like for native Dutch nouns. Furthermore, the model also suggests that anglicisms frequently receive the article of a Dutch cognate or translation. Third, the establishment of the anglicism has a significant influence on the article that is most often chosen by the respondents for anglicisms in Dutch.

The random factors in the regression model indicate that inter-respondent variation occurs for gender assignment to nominal anglicisms. A visualization of this variation shows that the amount of variation differs per anglicism. In addition, intra-respondent variation occurs as well: language users do not systematically choose a particular gender for anglicisms with similar properties. 
The predictions of the regression model for the combinations of variables that occur in the data reveal that the amount of disagreement on the gender of an anglicism is especially large for inanimate, established anglicisms that are listed with het and for non-established anglicisms that have a neuter gender Dutch equivalent. In particular, it shows that homogeneity in the speech community decreases if there is a conflict between the default article de and one or more factors that favor neuter gender.

In previous studies, the default article has been considered a last resort that will only be used when everything else (i.e. all other assignment rules) fails. In contrast, our analysis indicates that disagreement between the language users is more likely to occur for an anglicism that has a reason for receiving the non-default neuter gender, in comparison to an anglicism that has an equivalent that corresponds to the default anglicism article, common gender de. An explanation for this observation is that language users do not categorically follow the gender of the neuter gender favoring factor. Even when an anglicism has a very clear neuter gender cognate (like in the skateboard example), the respondents do not all unconditionally copy this gender. This means that the last resort interpretation might not suffice. 
This also contrasts with Geerts (1996). He assumes that in the case of a conflict between the default article de and the presence of a factor that favors neuter gender het, respondents straightforwardly choose the neuter article. Interestingly, our results indicate that in the case of such a conflict, there is more variability: respondents find it harder, rather than easier, to choose an article for the anglicism. Furthermore, in our dataset, respondents never categorically choose het for any anglicism.

Moreover, Geerts also argues that a clear hierarchy can be distinguished for the rules that apply to anglicisms. ${ }^{20}$ When multiple rules apply, some rules take precedence over others:

$\begin{array}{lllll}\text { cognate } & \text { prototypical } & > & \text { suffix }> & \text { gender of } \\ \text { gender } & \text { gender of } & \text { gender } & \text { translational } \\ & \text { semantic field } & & & \text { equivalent }\end{array}$

However, our dataset contains several anglicisms for which the gender cannot be explained by

this hierarchy. The anglicism member, for instance, receives neuter gender according to the factor article of lexical-semantic equivalent (due to its neuter translation lid), but as it is an animate noun, it should at the same time acquire common gender. Furthermore, it is nonestablished and infrequent. It seems that, due to the conflict between the multiple factors that

\footnotetext{
${ }^{20}$ According to Geerts, the gender of the translational equivalent is less crucial than the three other factors, which "predict the gender [of an anglicism] almost perfectly." (Geerts, 1996, p. 145)
} 
apply to the noun and the default gender, respondents disagree with each other a lot concerning the gender of member: 31 respondents use de, while 14 respondents select het.

Finally, by explicitly including both established and non-established anglicisms in our questionnaire, we were able to examine whether establishment in the speech community increases the amount of agreement about the gender of an anglicism. Our results indicate that, in contrast with what has been argued in most other studies on gender assignment to anglicisms, the amount of variation in our dataset is not only dependent on the degree of establishment of the anglicisms. The analysis shows that it also depends on the interplay of other factors that influence gender assignment: established anglicisms with neuter gender in the dictionary, for instance, show a high amount of variation as well, in comparison to established anglicisms that are listed with common gender.

While we were able to attenuate some hypotheses that were raised in previous research by showing that language users do not necessarily agree about the gender that is assigned to an anglicism, our study has some shortcomings that should be addressed in further research. First, the dataset only contains the responses of 45 respondents to the test sentences. Moreover, as all respondents are university students, follow-up research should include a higher number of 
respondents from a more stratified sample of the population. Even though we used the background of the respondent to operationalize some lectal features as independent variables, these factors did not reach significance in a multivariate environment. Using a larger, more stratified sample might uncover respondent-specific features that impact gender assignment to loanwords as well.

Second, while previous studies indicate that the gender associated with the suffix of an anglicism plays a role in gender assignment as well, we were not able to include this predictor in our regression model because of the low number of recently borrowed anglicisms with a suffix that is generally associated with neuter gender in Dutch. Exploratory analyses confirm that this predictor influences the gender of anglicisms as well: the proportion of neuter gender articles is significantly higher for anglicisms with suffix -ment, which is associated with neuter gender, than for anglicisms with a suffix associated with common gender. However, follow-up studies are needed to corroborate this result.

Third, although previous studies have argued that anglicisms belonging to particular semantic fields, such as breeds of dogs, drinks, collectives, sports and substances, often get a particular gender (see 3.2), this observation is not entirely supported by our analyses. The only evidence 
we obtained for the influence of semantic features is that animate anglicisms receive a significantly larger amount of common gender de than inanimate nouns. However, most of the semantic fields that have been discussed in previous studies could not be included in our analyses, because of the low number of anglicisms belonging to these fields. Therefore, an interesting extension to this study might be to focus on a different receptor language with a semantic gender system.

Fourth, the Van Dale dictionary, an implicitly normative dictionary of Dutch, was used in this study to determine whether an anglicism is established or not. Words are included in this dictionary if they are found regularly for an extensive period of time in the readily available language of the speech-making community (writers, teachers, scientists, journalists etc.; Den Boon \& Geeraerts, 2008). In the more recent editions of the dictionary, digitally available texts are used more and more to determine which lexical items should be included. For this reason, whether an anglicism is listed in the dictionary is often based on the frequency of the word. However, in some cases, frequency may not be on a par with the acceptedness or normative status of the word. 
To cope with this shortcoming, follow-up studies may want to take into account alternative, usage-based approaches for determining whether a noun is established in the speech community. One technique that has been used to investigate which factors influence the success of anglicisms in Dutch relies on the entire onomasiological profile of the concept in large corpora, i.e. the anglicism and all its (native) counterparts that can be used to express the same concept (Zenner et al., 2012; Zenner, Speelman, \& Geeraerts, 2014). This technique can also be used to quantify the degree of establishment of an anglicism by taking into account the relative weight of an anglicism vis-à-vis the frequency of its (native) synonymous expressions. A second method that can be envisaged is using the degree to which a noun is adapted to the receptor language in natural language data to make a decision about the establishment of an anglicism. Orthographic adaptation, for instance, can serve as an indication of a relatively high degree of establishment in the receptor language. Third, attitudinal data may also provide information about the acceptedness of non-native material in the receptor language.

Further extensions to this study are possible. First, the quantitative methodology that was applied in this paper also offers a new way of investigating the adaptation of loanwords from gendered source languages. Taking into account both the system of gender assignment to a loanword and variability in the homogeneity in the responses may reveal further issues that do 
not apply to borrowings from a non-gendered language like English. Second, as the gender system of Dutch is to a large extent arbitrary, a natural extension would be to concentrate on host languages with more rigorous gender systems. This could unveil whether the amount of variability in the degree of homogeneity in the speech community is also related to the arbitrariness of the Dutch gender system. Third, while the preponderance of the common gender article de is expected on the basis of previous studies on Dutch, few scholars have paid attention to the question why neuter gender was conventionalized in the first place for anglicisms in Dutch: why not rely on the default common gender alone for all anglicisms? One exception is Geerts (1970), who argues that an explanation may be a general process of deneutralization (ont-het-ting 'de-het-ing') in Dutch, which was first described by Van Haeringen (1951) for concrete mass nouns. Geerts proposes that the neuter gender in Dutch is a relatively closed category: nouns only receive this gender when very compelling reasons apply. For anglicisms, such compelling reasons are usually not available: they often refer to novel objects or concepts and they frequently lack the formal properties that are associated with neuter gender. However, a systematic diachronic quantitative study is necessary to corroborate this explanation. Despite its shortcomings, our paper still offers valuable new insights, and helps refine some of the hypotheses that have been discussed before. Methodologically, our multivariate approach 
enables us to demonstrate which factors influence the assignment of gender to anglicisms in

Dutch. Furthermore, this methodology allows us to show that the amount of homogeneity in the speech community does not solely depend on the degree of establishment of an anglicism.

Gender assignment to anglicisms in Dutch is not a categorical process, in contrast with what has been assumed in previous studies. On the theoretical level, we find clear evidence for the status of the common gender article de as the default article for anglicisms in Dutch. Regarding variation in the amount of agreement about the gender of an anglicism, the analysis indicates that homogeneity decreases when multiple rules apply. In sum, our analysis shows how the interplay between several factors influences both gender assignment to anglicisms in Dutch and variation in the homogeneity in the speech community.

\section{References}

Audring, J. (2009). Reinventing Pronoun Gender. LOT, Utrecht.

Baayen, H. R. (2008). Analyzing Linguistic Data. A Practical Introduction to Statistics Using R. Cambridge: Cambridge University Press.

Berteloot, A., \& Van der Sijs, N. (2003). Dutch. In M. Görlach (Ed.), English in Europe (pp. 3756). Oxford, New York: Oxford University Press. doi:10.1002/car.1158 
Biber, D., Johansson, S., Leech, G., Conrad, S., \& Finegan, E. (1999). Longman Grammar of Spoken and Written English. Harlow: Pearson Education.

Budzhak-Jones, S. (1997). Quantitative Analysis of Gender Assignment in Mono/Bilingual Discourse. Journal of Quantitative Linguistics, 4(1-3), 67-91.

Callies, M., Onysko, A., \& Ogiermann, E. (2012). Investigating gender variation of English loanwords in German. In C. Furiassi, V. Pulcini, \& F. Rodríguez González (Eds.), The Anglicization of European Lexis (pp. 65-89). Amsterdam/Philadelphia: John Benjamins Publishing Company.

Centraal Bureau voor de Statistiek. (2010). Standaard Beroepenclassificatie.

Chirsheva, G. (2009). Gender in Russian-English code-switching. International Journal of Bilingualism, 13(1), 63-90. doi:10.1177/1367006909103529

Clyne, M. (1992). Pluricentric languages: differing norms in different nations. Berlin/New York: Mouton de Gruyter.

Corbett, G. G. (1991). Gender. Cambridge: Cambridge University Press.

Corbett, G. G. (2014). Gender typology. In G. G. Corbett (Ed.), The Expression of Gender (pp. 87-130). 
De La Cruz Cabanillas, I., Tejedor Martínez, C., Díez Prados, M., \& Cerdá Redondo, E. (2007).

English loanwords in Spanish computer language. English for Specific Purposes, 26(1), 52-

78.

De Vogelaer, G., \& De Sutter, G. (2011). The geography of gender change: pronominal and adnominal gender in Flemish dialects of Dutch. Language Sciences, 33, 192-205.

doi:10.1016/j.langsci.2010.02.001

Den Boon, T., \& Geeraerts, D. (2008). Van Dale Groot Woordenboek van de Nederlandse Taal (14th ed.). Utrecht / Antwerpen: Van Dale Lexicografie.

Faraway, J. J. (2006). Extending the Linear Model with R. Generalized Linear, Mixed Effects and Nonparametric Regression models. Boca Raton: Chapman \& Hall.

Geerts, G. (1970). De nominale klassifikatie van ontleningen. De Nieuwe Taalgids, 63, 43-53.

Geerts, G. (1996). De genusbepalende eigenschappen van Engelse leenwoorden in het Nederlands. Verslagen En Mededelingen van de Koninklijke Academie Voor Nederlandse Taal- En Letterkunde, 106(2-3), 137-146.

Haeseryn, W., Romijn, K., Geerts, G., De Rooij, J., \& Van den Toorn, M. C. (1997). Algemene Nederlandse Spraakkunst. Groningen/Deurne: Martinus Nijhoff uitgevers/Wolters Plantyn. 
Hamans, C. (2009). Het geslacht van leenwoorden. In W. Burger \& M. Pienaar (Eds.), Die tand van die tyd. Opstelle opgedra aan Jac Conradie (pp. 24-25). Stellenbosch: Sun Media.

Instituut voor Nederlandse Lexicologie, \& Nederlandse Taalunie. (2005). Het Groene Boekje. Woordenlijst Nederlandse Taal.

Koenen, L., \& Smits, R. (1992). Peptalk. De Engelse woordenschat van het Nederlands. Amsterdam: Nijgh \& Van Ditmar.

Kraaikamp, M. (2012). The semantics of the Dutch gender System. Journal of Germanic Linguistics, 24(3), 193-232.

Muysken, P. (2000). Bilingual Speech: A Typology of Code-Mixing. Cambridge: Cambridge University Press.

Onysko, A. (2007). Anglicisms in German: Borrowing, lexical productivity, and written codeswitching. Berlin: de Gruyter.

Onysko, A., Callies, M., \& Ogiermann, E. (2013). Gender variation of anglicisms in German: the influence of cognitive factors and regional varieties. Poznan Studies in Contemporary Linguistics, 49(1), 103-136.

Oxford University Press. (2013). Historical Thesaurus of the OED. 
Poplack, S., Pousada, A., \& Sankoff, D. (1982). Competing influences on gender assignment: variable process, stable outcome. Lingua, 57, 1-28.

Posthumus, J. (1996). Het woordgeslacht van Engelse leenwoorden. Onze Taal, 65(11), 279.

Quirk, R., Greenbaum, S., Leech, G., \& Svartvik, J. (1985). A comprehensive grammar of the English language. New York: Longman.

R. Development Core Team. (2009). R: A Language and Environment for Statistical Computing.

(R. D. C. Team, Ed.)R Foundation for Statistical Computing (Vol. 1). R Foundation for Statistical Computing. doi:10.1007/978-3-540-74686-7

Rothe, A. (2014). On the variation of gender in nominal language mixings. In E. Zenner \& G.

Kristiansen (Eds.), New Perspectives on Lexical Borrowing: Onomasiological, Methodological and Phraseological Innovations (pp. 191-223). Boston/Berlin: De Gruyter Mouton.

Schenck, A. (1985). Genusbepalende eigenschappen van Engelse leenwoorden in het Nederlands. KU Leuven.

Smead, R. N. (2000). On the assignment of gender to Chicano Anglicisms: Processes and results. The Bilingual Review, 23(3), 277-297. 
Thornton, A. M. (2009). Constraining gender assignment rules. Language Sciences, 31(1), 1432. doi:10.1016/j.langsci.2007.09.003

Van Dale Lexicografie (Ed.). (2006). Van Dale Groot woordenboek Engels-Nederlands. Utrecht.

Van Haeringen, C. B. (1951). Genusverandering bij stofnamen. De Nieuwe Taalgids, 44, 7-14.

Verhoeven, G., \& Jansen, F. (1996). Het woordgeslacht van Engelse leenwoorden. Onze Taal, 65(6), 156-157.

Violin-Wigent, A. (2006). Gender assignment to nouns codeswitched into French: Observations and explanations. International Journal of Bilingualism, 10(3), 253-276.

doi:10.1177/13670069060100030101

Zenner, E. (2013). Cognitive Contact Linguistics. The macro, meso and micro influence of English on Dutch. KU Leuven.

Zenner, E., Speelman, D., \& Geeraerts, D. (2012). Cognitive Sociolinguistics meets loanword research: Measuring variation in the success of anglicisms in Dutch. Cognitive Linguistics, 23(4), 749-792. doi:10.1515/cog-2012-0023

Zenner, E., Speelman, D., \& Geeraerts, D. (2014). Core vocabulary, borrowability and entrenchment: A usage-based onomasiological approach. Diachronica, 31(1), 74-105. 
doi:10.1075/dia.31.1.03zen 
Appendix: list of anglicisms

\section{Established nouns}

\begin{tabular}{|c|c|c|c|}
\hline anglicism & gender in Van Dale & gender Van Dale (binary) & establishment \\
\hline ace & both & het & established de \\
\hline aquaplaning & none & de & established het \\
\hline assist & de & de & established de \\
\hline babyfoon & de & de & established de \\
\hline baseballbat & het & het & established het \\
\hline basketbal & het & het & established het \\
\hline black-out & de & de & established de \\
\hline blooper & de & de & established de \\
\hline braindrain & none & de & established de \\
\hline briefing & de & de & established de \\
\hline bulldog & de & de & established de \\
\hline busticket & both & het & established het \\
\hline callgirl & de & de & established de \\
\hline carpooling & het & het & established de \\
\hline cashflow & de & de & established de \\
\hline chick & het & het & established de \\
\hline clash & het & het & established de \\
\hline click & de & de & established de \\
\hline column & de & de & established de \\
\hline combo & de & de & established het \\
\hline computersoftware & de & de & established de \\
\hline cover & none & de & established de \\
\hline creditcard & de & de & established de \\
\hline disc & de & de & established de \\
\hline diskette & de & de & established de \\
\hline empathie & het & het & established de \\
\hline entertainment & het & het & established het \\
\hline
\end{tabular}




\begin{tabular}{|c|c|c|c|}
\hline anglicism & gender in Van Dale & gender Van Dale (binary) & establishment \\
\hline escalatie & none & de & established de \\
\hline establishment & de & de & established het \\
\hline extra-time & de & de & established de \\
\hline facelift & none & de & established de \\
\hline franchising & de & de & established de \\
\hline freelancester & none & de & established de \\
\hline gangster & het & het & established de \\
\hline gossip & de & de & established de \\
\hline hippie & none & de & established de \\
\hline hotelmanager & de & de & established de \\
\hline hovercraft & het & het & established de \\
\hline image & het & het & established het \\
\hline input & de & de & established de \\
\hline intercom & none & de & established de \\
\hline jack & het & het & established het \\
\hline jingle & de & de & established de \\
\hline jogger & de & de & established de \\
\hline knowhow & de & de & established de \\
\hline loafer & de & de & established de \\
\hline lovestory & de & de & established de \\
\hline majorette & het & het & established de \\
\hline marketing & de & de & established de \\
\hline mummy & de & de & established de \\
\hline panty & de & de & established de \\
\hline party & de & de & established de \\
\hline patchwork & het & het & established het \\
\hline popart & none & de & established de \\
\hline recycling & de & de & established de \\
\hline release & de & de & established de \\
\hline researcher & de & de & established de \\
\hline rock'n'roll & de & de & established de \\
\hline
\end{tabular}




\begin{tabular}{|c|c|c|c|}
\hline anglicism & gender in Van Dale & gender Van Dale (binary) & establishment \\
\hline sensor & none & de & established de \\
\hline sit-in & de & de & established de \\
\hline skateboard & het & het & established het \\
\hline smog & de & de & established de \\
\hline snowboarder & none & de & established de \\
\hline sound & het & het & established de \\
\hline spot & het & het & established de \\
\hline spray & de & de & established de \\
\hline statement & de & de & established het \\
\hline stationwagon & de & de & established de \\
\hline sticker & none & de & established de \\
\hline supercomputer & de & de & established de \\
\hline supermarkt & de & de & established de \\
\hline suspense & de & de & established de \\
\hline talkshow & de & de & established de \\
\hline tenniscoach & de & de & established de \\
\hline tennismatch & de & de & established de \\
\hline track & het & het & established de \\
\hline underdog & de & de & established de \\
\hline voucher & de & de & established de \\
\hline
\end{tabular}




\section{Non-established nouns}

\begin{tabular}{|l|l|l|}
\hline anglicism & corpus frequency & frequency (categorical) \\
\hline achievement & 168 & infrequent \\
\hline American dream & 1743 & frequent \\
\hline award & 2515 & frequent \\
\hline battle & 695 & frequent \\
\hline beach & 1111 & frequent \\
\hline believer & 184 & infrequent \\
\hline bodypainting & 281 & infrequent \\
\hline boogie & 566 & frequent \\
\hline camping ground & 767 & frequent \\
\hline career day & 4240 & frequent \\
\hline catsuit & 100 & infrequent \\
\hline channel & 134 & infrequent \\
\hline character & 140 & infrequent \\
\hline check-in & 811 & frequent \\
\hline chill-out & 200 & infrequent \\
\hline comedian & 1905 & frequent \\
\hline concept car & 1656 & frequent \\
\hline container ship & 151 & infrequent \\
\hline contest & 326 & frequent \\
\hline cooler & 243 & infrequent \\
\hline copy & 158 & infrequent \\
\hline countdown & 160 & infrequent \\
\hline dancefloor & 358 & frequent \\
\hline demand & 369 & frequent \\
\hline development & 974 & \\
\hline director & 3704 & frequent \\
\hline draft & 304 & \\
\hline dress & 212 & infent \\
\hline e-learning & frequent & \\
\hline engine & 126 & \\
\hline
\end{tabular}




\begin{tabular}{|c|c|c|}
\hline anglicism & corpus frequency & frequency (categorical) \\
\hline error & 285 & infrequent \\
\hline exit-poll & 211 & infrequent \\
\hline fairness & 198 & infrequent \\
\hline football & 1313 & frequent \\
\hline freebee & 133 & infrequent \\
\hline gallery & 142 & infrequent \\
\hline guesthouse & 188 & infrequent \\
\hline hometown & 117 & infrequent \\
\hline hospitality & 111 & infrequent \\
\hline indian summer & 1682 & frequent \\
\hline inspector & 228 & infrequent \\
\hline it-girl & 2222 & frequent \\
\hline key & 889 & frequent \\
\hline leisure & 237 & infrequent \\
\hline mall & 313 & frequent \\
\hline member & 150 & infrequent \\
\hline nanny & 375 & frequent \\
\hline network & 512 & frequent \\
\hline nickname & 134 & infrequent \\
\hline noise & 777 & frequent \\
\hline opportunity & 191 & infrequent \\
\hline package & 185 & infrequent \\
\hline pay & 744 & frequent \\
\hline printing & 145 & infrequent \\
\hline publicity & 115 & infrequent \\
\hline publishing & 145 & infrequent \\
\hline queen & 1042 & frequent \\
\hline quizzer & 107 & infrequent \\
\hline rate & 627 & frequent \\
\hline reality & 1529 & frequent \\
\hline resource & 252 & infrequent \\
\hline
\end{tabular}


66

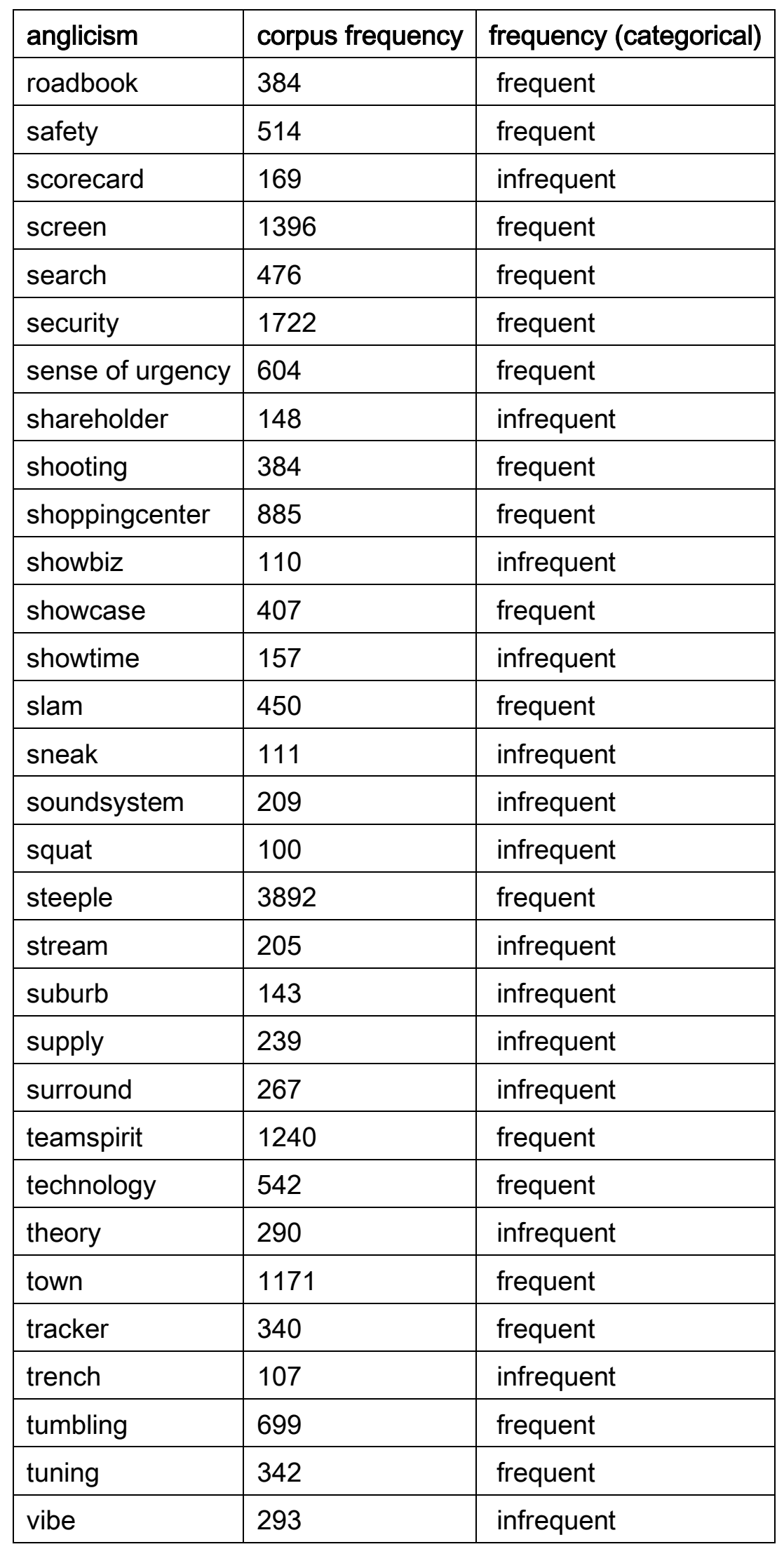




\begin{tabular}{|l|l|l|}
\hline anglicism & corpus frequency & frequency (categorical) \\
\hline view & 586 & frequent \\
\hline wall & 510 & frequent \\
\hline wash & 191 & infrequent \\
\hline witch & 184 & infrequent \\
\hline youngster & 944 & frequent \\
\hline
\end{tabular}

